\title{
COMMENTARY
}

\section{Determining relevant cortisol concentrations in critically ill patients}

\author{
Rizwan A Manji and Anand Kumar* \\ See related research by Cohen et al., http://ccforum.com/content/13/6/R189
}

\begin{abstract}
The importance of adrenal function to survival in critically ill patients has been established; however, identifying the best method to diagnose adrenal insufficiency has been problematic. Multiple methods of determining adrenal function have been developed, each with its advantages and disadvantages.

Serum-free cortisol levels are probably the most accurate, although obtaining this result is technically demanding. Cohen and colleagues investigated the feasibility of measuring tissue cortisol levels in burn patients and whether tissue cortisol levels could be used as a surrogate for plasma-free cortisol levels.
\end{abstract}

In the previous issue of Critical Care, Cohen and colleagues [1] conducted a feasibility study and examined 10 burn patients and 3 healthy volunteers to determine whether there were correlations between tissue cortisol levels and plasma-free cortisol levels. The authors hypothesized that tissue cortisol levels are more relevant as this is what binds to cellular cortisol receptors and leads to cortisol-associated physiological changes seen. The authors concluded that obtaining tissue cortisol levels was feasible, but there was no correlation between tissue and plasma cortisol levels.

Different methods of measuring cortisol levels are used. The most commonly used method measures total serum cortisol, which is free and protein (transcortin and albumin)-bound cortisol. Measuring total cortisol has poor sensitivity and specificity and high variability in critically ill patients [2]. In addition, the immunoassays used to determine total cortisol are subject to interference, with heterophile antibodies present in some critically ill patients [3]. Using mass spectroscopy to

*Correspondence: akumar61@yahoo.com

Cardiac Sciences Program, I. H. Asper Clinical Research Institute, CR3014-369 Taché Avenue, Winnipeg, MB, Canada, R2H 2A6 measure cortisol is more specific though not widely available. Some have suggested using ratios like the free cortisol index [4] to calculate the free cortisol amount; however, these methods do not account for all proteins such as albumin, they require measurement of transcortin (a lab test not widely available), and they do not adequately account for any dilutional effects of massive resuscitation or of other hormonal changes (for example, vasopressin) that may affect plasma cortisol levels [5]. Cosyntropin stimulation testing has been advocated by some [6-8] to determine whether there is relative adrenal insufficiency; however, the values used as a standard for 'inadequate response' were determined in healthy adults (not critically ill patients), and there is still a high level of variability in measurements, even in the same patient $[9,10]$. The most accurate active cortisol measure that is clinically relevant is serum-free cortisol $[9,11]$. Measuring serum-free cortisol, however, is very difficult to perform and thus is not widely available. A widely available and less costly test that does correlate well with plasma-free cortisol levels is to measure salivary cortisol levels [12]. However, it is difficult to get an adequate saliva sample in critically ill patients [13].

The study of Cohen and colleagues [1] is one of the first to examine tissue cortisol levels. Although measuring tissue cortisol may be more pathophysiologically relevant than measuring plasma levels, it is not clear how measuring cortisol levels in tissues relates to relevant outcomes of decreased vasopressor use and improved mortality. There have been many studies examining plasma cortisol levels and relating them, or treatment of relative adrenal insufficiency, with relevant outcomes [6,7]. To our knowledge, there are no studies linking tissue cortisol levels to relevant outcomes. It is known that there is tissue resistance to glucocorticoids, potentially due to local cytokine production leading to downregulation and decreased affinity of glucocorticoid receptors and post-receptor alterations [14]. Thus, cortisol levels may be very different in different tissues, raising the question of what tissue the cortisol should be measured in. With massive resuscitation, tissues can also become very edematous and this may dilute tissue 
cortisol levels, again raising the questions of when to obtain tissue cortisol levels, where to obtain the levels, and the accuracy of the result. Cortisol has effects on gluconeogenesis, vascular tone, endothelial integrity, and angiotensinogen synthesis and has anti-inflammatory effects on the immune system [15]. All of these effects of cortisol affect the entire organism, suggesting that measuring circulating cortisol, rather than tissue cortisol, may be more relevant and useful from a clinical point of view. Efforts should continue to determine more efficient and effective ways to measure serum-free cortisol levels or related markers so that these assays can be widely used in a way that can benefit critically ill patients in the intensive care unit.

\section{Competing interests}

The authors declare that they have no competing interests.

Published: 8 February 2010

\section{References}

1. Cohen J, Deans R, Dalley A, Lipman J, Roberts M, Venkatesh B: Measurement of tissue cortisol levels in patients with severe burns: a preliminary investigation. Crit Care 2009, 13:R189.

2. Clark PM, Neylon I, Raggatt PR, Sheppard MM, Steward PM: Defining the normal cortisol response to the short synacthen test: implications for the investigation of hypothalamic-pituitary disorders. Clin Endocrinol (Oxf) 1998, 49:287-292.

3. Bolland MJ, Chiu WW, Davidson JS, Croxson MS: Heterophile antibodies may cause falsely lowered serum cortisol values. J Endocrinol Invest 2005 28:643-645

4. Le Roux CW, Chapman GA, Kong WM, Dhillo WS, Jones J, Alaghband-Zadeh J: Free cortisol index is better than serum total cortisol in determining hypothalamic-pituitary-adrenal status in patients undergoing surgery. J Clin Endocrinol Metab 2003, 88:2045-2048.
5. Taylor KM, Bain WH, Jones JV, Walker MS. The effect of hemodilution on plasma levels of cortisol and free cortisol. J Thorac Cardiovasc Dis 1976, 72:57-61.

6. Rothwell PM, Udwadia ZF, Lawler PG: Cortisol response to corticotrophin and survival in septic shock. Lancet 1991, 337:582-583.

7. Annane D, Sebille V, Charpentier C, Bollaert PE, Francois B, Korach JM, Capellier G, Cohen Y, Azoulay E, Troche G, Chaumet-Riffaut P, Bellissant E: Effect of treatment with low doses of hydrocortisone and fludrocortisone on mortality in patients with septic shock. JAMA 2002, 288:862-871.

8. Annane D, Sebille V, Troche G, Raphael JC, Gajdos P, Bellissant E: A 3-level prognostic classification in septic shock based on cortisol levels and cortisol response to corticotropin. JAMA 2000, 283:1038-1045.

9. Hamrahian AH, Oseni TS, Arafah BM: Measurements of serum free cortisol in critically ill patients. N Engl J Med 2004, 350:1629-1638.

10. Loisa P, Uusaro A, Ruokonen E: A single adrenocorticotropic hormone stimulation test does not reveal adrenal insufficiency in septic shock. Anesth Analg 2005, 101:1792-1798.

11. Ho JT, Al-Musalhi H, Chapman MJ, Quach T, Thomas PD, Bagely CJ, Lewis JG, Torpy DJ: Septic shock and sepsis: a comparison of total and free plasma cortisol levels. J Clin Endocrinol Metab 2006, 91:105-114.

12. Laudat MH, Cerdas S, Fournier C, Guiban D, Guilhaume B, Luton JP: Salivary cortisol measurement: a practical approach to assess pituitary-adrenal function. J Clin Endocrinol Metab 1988, 66:343-348.

13. Nishiyama FJ, Thlaygi H, Zayour DH, Hejal R, Arafah BM: Increased salivary cortisol concentrations in critically ill patients: a practical approach in determining free cortisol in the circulation. Program of the 87th Annual Meeting of the Endocrine Society; 3 to 6 June 2005; San Diego, CA. Abstract P3-440.

14. Schaaf MJ, Cidlowski JA: Molecular mechanisms of glucocorticoid action and resistance. J Steroid Biochem Mol Biol 2002, 83:37-48

15. Arafah BM: Hypothalamic pituitary adrenal function during critical illness: limitations of current assessment methods. J Clin Endocrinol Metab 2006, 91:3725-3745.

doi:10.1186/cc8225

Cite this article as: Manji RA, KumarA: Determining relevant cortisol concentrations in critically ill patients. Critical Care 2010, 14:113. 